\title{
Snyder Unit Hydrograph and GIS for Estimation of Flood for Un-Gauged Catchments in Lower Tapi Basin, India
}

\section{Sudhakar BS 1 , Anupam $\mathrm{KS}^{2}$ and Akshay $\mathrm{OJ}^{3}$}

${ }^{1}$ Institute of Science, Nirma University Science \& Technology, Ahmedabad-382481, India

${ }^{2}$ Institute of Engineering \& Technology, J.K Lakshmipat Universitsy, Jaipur-302026, India

${ }^{3}$ Department of Civil Engineering, Pandit Dindayal Petroleum University, Gandhinagar, India

\begin{abstract}
In the flood prone catchments, it is needful to estimate the discharge, standard lag time, time of peak, and flood response of each watershed in the basin. The SUH method offers considerable advantage over others, and thus, has been chosen for estimation of flood response, contribution of flooding potential, percentage of flood volume for 25 sub-watersheds. The discretion of sub-watershed for estimation of peak discharge, time of peak, alternate lag time, and width of SUH at $50 \%$ and $75 \%$ of peak found to offer advantages over other methods. This paper considers Snyder Unit Hydrograph (SUH) with GIS based spatial database for calculating discharge at Lower Tapi Basin (LTB). The hydrological parameters of each sub-watershed such as river length, length of centroid, spatial area, land use, lateral slope, and terrain and soil factors have been extracted from GIS database. The geo-data has been combined with topographical maps to produce a digital elevation model (DEM) of $50 \mathrm{~m}$ cell size. The analysis for all 25 subwatersheds exhibit that $35.07 \mathrm{~m}^{3} / \mathrm{s}$ and $4.55 \mathrm{~m}^{3} / \mathrm{s}$ and 13.23 hours and 4.33 hours have been highest and lowest peak flow and time of peak respectively. The SUH model has been validated for peak discharge at a gauge site Amli $\left(E 73^{\circ} 23^{\prime} \mathrm{N}^{2} 1^{\circ}{ }^{2} 3^{\prime}\right)$ where discharge data were collected during 2010 and 2011 monsoon. A comparison between measured and SUH modelled discharge shows good fit within a mean variability range of $5-7 \%$. The SUH methods ability to estimate hydrological parameters including peak flow discharge shows wider replication for un-gauged catchments.
\end{abstract}

Keywords: Hydrological modelling, Discharge estimation, Snyder unit hydrograph, GIS

\section{Introduction}

In the flood prone catchments it is needful to calculate peak flood discharge from each watershed. It is desirous to estimate lag time, time to peak, and flood response of each watershed, as above parameters affect the channel flow and peak flood formation. Therefore, reliable estimation of them is of prime importance and more so for ungauged catchments. The recent International Association of Hydrological Sciences (IAHS) initiative on prediction in ungauged basins (PUB) has opened opportunities to carry-out research in data poor or ungauged basin. In India most of the watersheds below $500 \mathrm{~km}^{2}$ are ungauged or sufficient hydrological data is not available [1-3]. Lower Tapi basin a geographical area of $1998 \mathrm{~km}^{2}$ and a river length of $106 \mathrm{~km}$ between Ukai dam and Hazira is one among ungauged catchments. The basin has been receiving periodic floods occurred every 3-4 years interval. The recent flood in the basin has been during 6-14 August 2006 causing more than INR 22,000 crore ( US\$ 4.5 billion) economic loss and 300 people being killed.

Traditional techniques for design flood estimation use historical rainfall-runoff data and unit hydrographs derived from them and to overcome such difficulties, the use of physically based rainfall-runoff estimation methods such as the geomorphological instantaneous unit hydrograph (GIUH) have evolved [4]. Several methods on peak flood discharge and associated parameters estimation have been suggested in the literature for ungauged basins. However, the parameter reliability between various methods varies to a large extent and none found to be suitable universally.

Sharma et al. [5] have estimated flooding potential watershed using SCS-CN method for identification of watershed, for a part of lower Tapi Basin. The data calculation gives good results for rainfall runoff modelling and suggested that the method may be good tool for runoff estimation for lower Tapi basin and un-gauged catchment like Varekhadi catchment. Sherman [6] proposed an advance theory of unit hydrograph for estimating surface runoff in gauged basins [4]. This theory has been considered an important contribution to the field of hydrology in deriving the flood hydrograph. However, UH theory has limitation on precise runoff prediction due to limiting assumptions. Snyder [7] developed a set of empirical equation for synthetic unit hydrograph (SUH) in large number of catchments in Appalachian Highland of eastern United State [5]. The SUH method has better acceptability for ungauged basins unlike the Sherman's Unit Hydrograph method. Literature supports that SUH method has applications for watersheds having large variability ranging from 25 $\mathrm{km}^{2}$ to $25,000 \mathrm{~km}^{2}$.

Hoffmeister et al. [8] in their research work, developed a synthetic unit hydrograph for an un-gauged basin in New Zealand [6]. The authors tested three different methods viz. Snyder method, Common's dimensionless method, SCS dimensionless hydrograph for catchment each represent dominant hydrological and physiographic characteristics of that region. Their research results indicate that Snyder's UH method gives best results as compared to later ones. In other study, Wayal et

*Corresponding author: Sudhakar BS, Institute of Science, Nirma University Science \& Technology, Ahmedabad- 382481, India, Tel: 02717241911; E-mail: sudhakar.sharma@nirmauni.ac.in

Received January 26, 2015; Accepted February 16, 2015; Published February 19,2015

Citation: Sudhakar BS, Anupam KS, Akshay OJ (2015) Snyder Unit Hydrograph and GIS for Estimation of Flood for Un-Gauged Catchments in Lower Tapi Basin India. Hydrol Current Res 6: 195. doi:10.4172/2157-7587.1000195

Copyright: (c) 2015 Sudhakar BS, et al. This is an open-access article distributed under the terms of the Creative Commons Attribution License, which permits unrestricted use, distribution, and reproduction in any medium, provided the original author and source are credited. 
al. [9] has derived empirical equations for ungauged catchement based on snyder's relation on SUH in India [7]. The study was carried out in parts of Krishna and Pennar river basin in South India. The synthetic relations derived by Wayal [9] can be applied only under watersheds having similar topographical and climatologically regions like Krishna and Pennar. Later Adebayo [10] developed unit hydrograph and compared the performance of Snyder's method, SCS method, Gray's method for eight sub-watersheds in south-west Nigeria [8]. The authors suggested use of SCS-method since topographic, climatic and basin properties at daily time scale were not available. The authors found SCS-method suitable as compared to others Abid et al. [11] compared the runoff hydrographs estimated by the SCS and Snyder UH models with the observed runoff hydrographs in Kasilian watershed [9]. The authors observed that the calculated runoff hydrographs by these models have good fitness with observed runoff hydrographs. Limantara [12] has been of the view that SUH could become the source of some important information that is necessary for the reliable of hydraulic structures [10]. In his paper he analyzed the design flood hydrograph through the uses of areal rain data inputs. Therefore, this paper uses SUH method to estimate peak flood discharge for partial gauged site in LTB catchment in India.

\section{Study area description}

Tapi is the second largest westward draining inter-state river in India after mighty River Narmada. The basin finds its outlet in the Arabian Sea after passing Surat city in Gujarat that is bounded on the three sides by the hill ranges. The Tapi River is divided in three zones, viz. Upper Tapi basin, Middle Tapi Basin, and Lower Tapi Basin (LTB). The portion between Ukai Dam to Arabian Sea has been considered as LTB, mainly occupying Surat and Hazira twin city along with tens of small towns and villages along the river course. The lower tapi basin extends over an area of $1998 \mathrm{~km}^{2}$. The Surat and Hazira twin cities are downstream of Ukai Dam almost $106 \mathrm{~km}$ distance and are affected by recurrence floods at regular intervals.

The Geographic Location of study area is Longitude $72^{\circ} 42^{\prime}$ to $73^{\circ} 40^{\prime}$ and Latitude $21^{\circ} 08^{\prime}$ to $21^{\circ} 30^{\prime}$ (Figure 1). LTB receive an average annual rainfall of $1376 \mathrm{~mm}$, and these heavy downpours result into devastating floods and water loggings mainly between Ukai dam and
Hazira town downstream. The major crops grown in the study area are cotton and maize followed by Soybean. The land use prevailing in the study area is mixed forest, agriculture land, rural and urban settlements. The topography of Surat is gently sloping and flat. Therefore, it can be stated that study area has multiple problems in flood formation. This necessitates the need for monitoring and solutions that are simple, based on Remote Sensing and GIS, require use of Hydrological Modelling. The main reasons for flooding in Surat depend on heavy rainfall and discharge due to high water levels from Ukai dam. Therefore, the flood problems of the river system are inundation due to over flowing of the banks. High tide during certain period also play significant role in flood formation for this $106 \mathrm{~km}$ stretch.

\section{Methodology}

The research methodology used for estimation of discharge using SUH method consist of three steps viz. geo-database development, estimation of hydrological parameters and field data collection (Figure 2). The detailed description on each step has been given below.

\section{Geo-database development}

The geo-database for LTB has been created using topological maps, satellite remote sensing images and field surveys using GPS. Topographical maps at 1:50000 scales were collected, geo-referenced, and digitized for themes such as contours, level points, streams, and watershed boundary. Based on information obtained from maps, attribute properties to various themes have been assigned. The geodata base on above listed themes has been cross-checked with field and attributes were revised. It was decided to carry out engineering survey for almost 327 cross-sections across the Tapi River. A digital elevation model (DEM) for $50 \mathrm{~m}$ cell size and $2.5 \mathrm{~m}$ vertical accuracy for LTB has been generated (Figure 3). The accuracy assessment carried on DEM for selected locations shows a good fit and has been in coherence with actual elevation values. The DEM has been considered as basis for delineation of sub-watershed boundary, geographical areas and longitudinal slopes along river stretches. The 25 sub-watersheds for LTB has been delineated using hydrological model software BASIN (EPA, 2007) on DEM (Figure 4). A threshold area of $10 \mathrm{~km}^{2}$ has been considered for delineation of sub-watershed boundary. The other hydrological parameters such as watershed area, river length, and

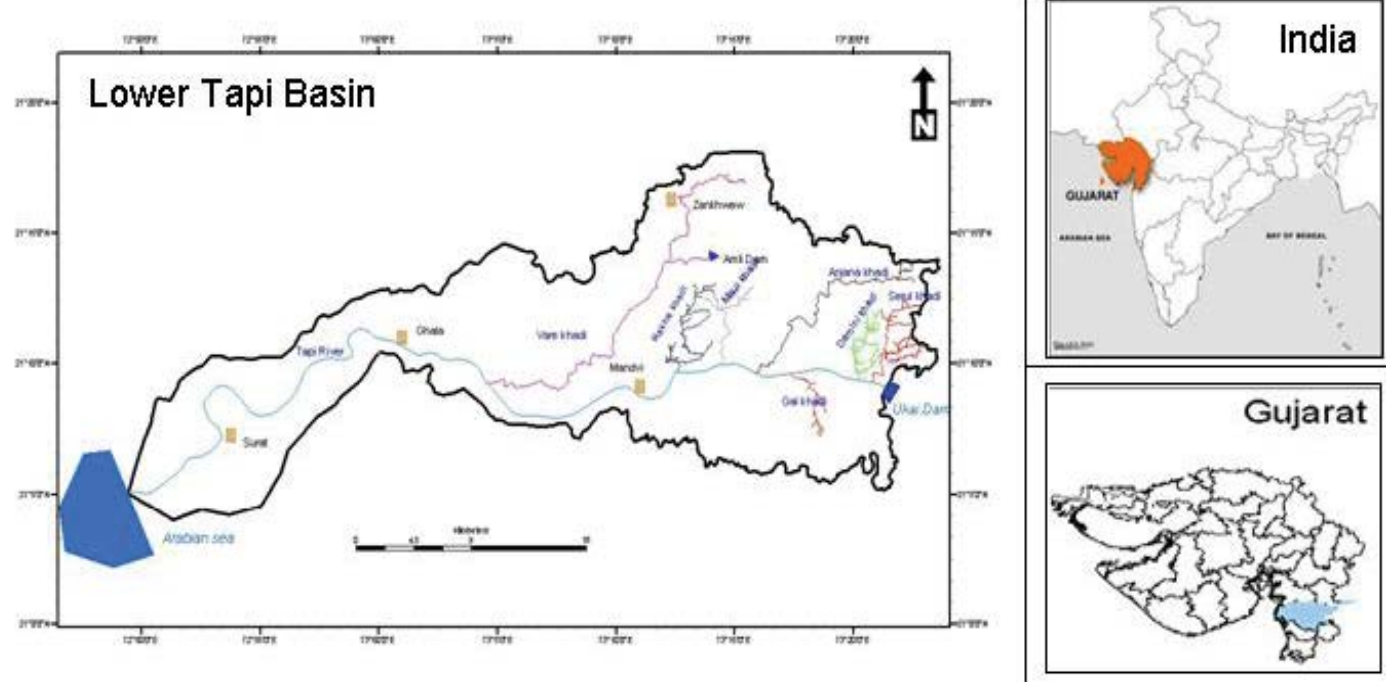

Figure 1: Study area (Lower Tapi Basin). 


\section{DIGITAL ELEVATION MODEL}
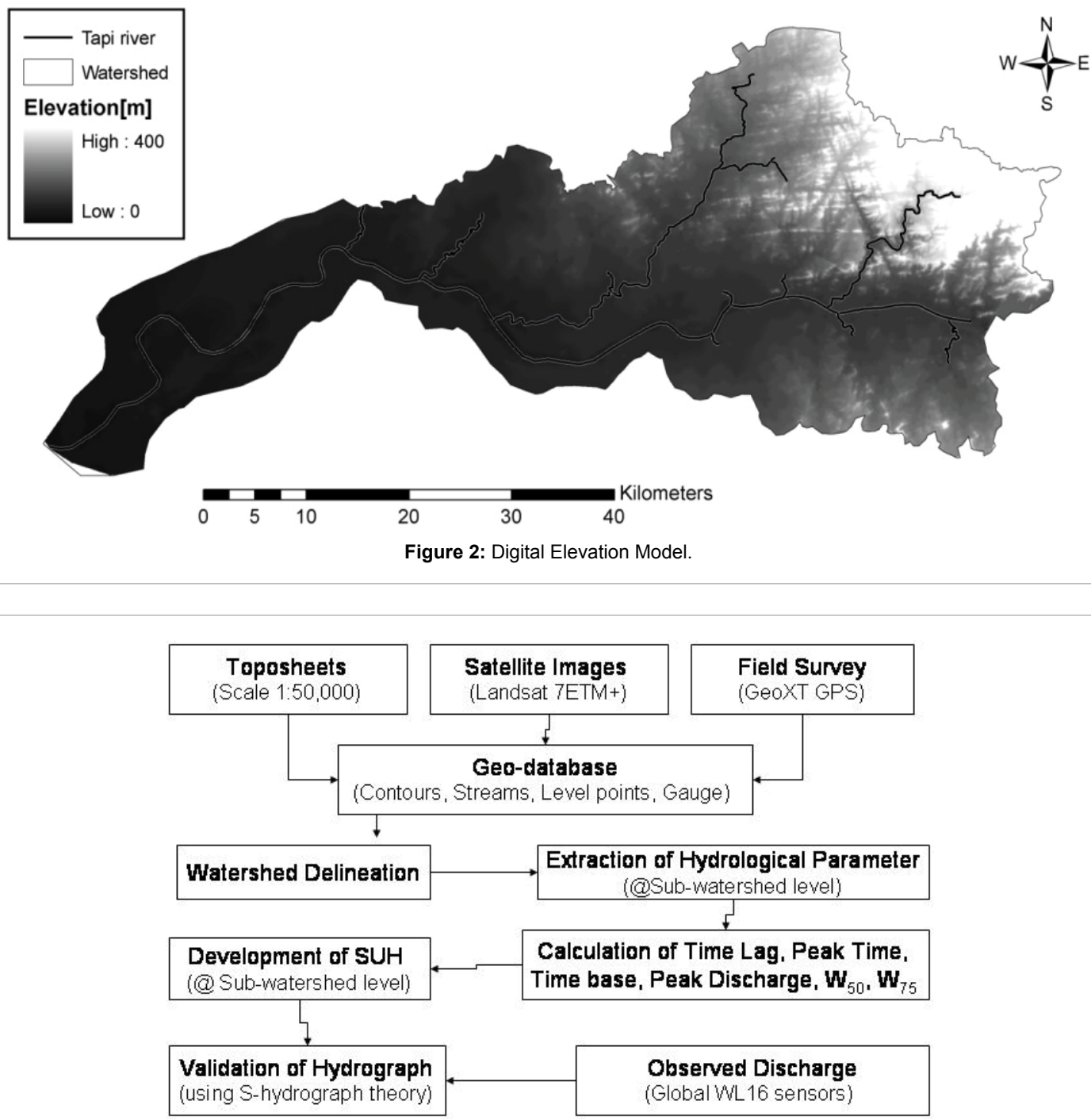

Figure 3: Methodology.

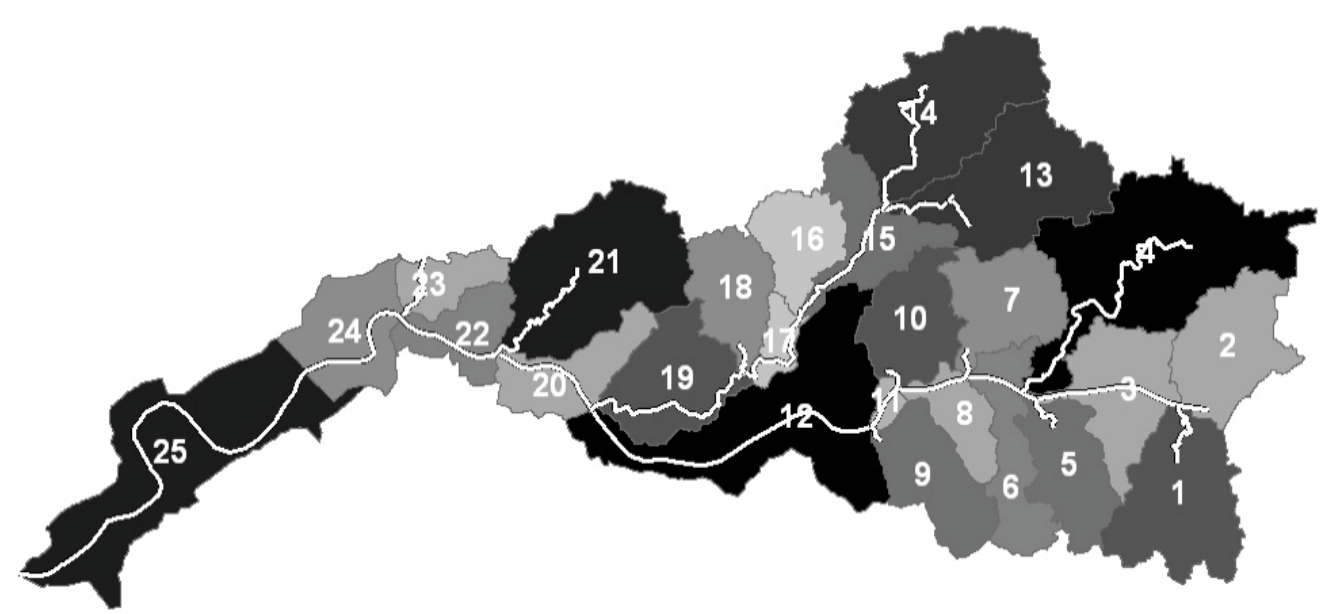

Figure 4: Sub-watersheds of LTB. 
length of centroid have been derived using measurement tool in ArcGIS.

\section{Estimation of hydrological parameter}

The following methodology has been used for calculation of hydrological parameters resulting into Snyder unit hydrograph (SUH). The steps involved in the calculation have been detailed out from equation (1) to (8) below [11,12].

The Snyder standard lag time $\left(\mathrm{T}_{\mathrm{lag}}\right)$ [in hours];

$$
T_{\text {lag }}=C_{t}\left(L \times L_{c a}\right)^{0.3}
$$

Where the terms,

\section{$\mathrm{Ct}=\mathrm{Lag}$ Coefficient $[1.2-2.2]$ dependent upon basin properties}

$\mathrm{L}=$ main channel length from basin outlet to upstream watershed boundary $[\mathrm{km}]$

$\mathrm{L}_{\mathrm{ca}}=$ main channel length from outlet to a point opposite the Centre of gravity $[\mathrm{km}]$

The duration of $\mathrm{UH}\left(\mathrm{T}_{\mathrm{d}}\right)$ [in hours];

$$
T_{d}=\frac{T_{l a g}}{5.5}
$$

As the term $\mathrm{T}_{\mathrm{d}}$ is variable for each watershed and depends on shape and size. We propose to prepare SUH for each sub-watershed having common time duration of 1 hour. Therefore, above calculated time duration $\left(\mathrm{T}_{\mathrm{d}}\right)$ is not desired duration. The alternative lag time [ $\mathrm{T}_{\text {lag.alt] }}$ can be computed using equation (3);

$$
T_{\text {lag.alt }}=T_{\text {lag }}+0.25\left(T_{d a}-T_{d}\right)
$$

Where, $\mathrm{T}_{\mathrm{d}}=$ Previously Calculated duration [in hours], $\mathrm{T}_{\mathrm{da}}=\mathrm{New}$ desired duration [in hours]

Time of Peak $\left(\mathrm{T}_{\mathrm{p}}\right)$ [in hours]:

$$
T_{p}=\frac{T_{d}}{2}+T_{\text {lag }, a l t}
$$

The terms $\mathrm{T}_{\mathrm{d}}$ and $\mathrm{T}_{\text {lag.alt }}$ have been obtained from equation (2) and equation (3).

Peak Discharge $\left(Q_{p}\right)$ [in $\left.\mathrm{m}^{3} / \mathrm{s}\right]$ from each sub-watershed is calculated using below equation:

$$
Q_{p}=\frac{2.78 \times A \times C_{p}}{T_{\text {lag, lag }}}
$$

Where, $A=$ area of sub-watershed [in $\left.\mathrm{km}^{2}\right], \mathrm{C}_{\mathrm{p}}=$ Peak flow coefficient [0.5- 0.7] that dependent upon basin characteristics.

Time base of the UH [in days] is calculated as follows:

$$
T_{\text {base }}=3+\frac{T_{\text {lag, alt }}}{8}
$$

Furthermore, Snyder proposed that shape of Unit Hydrograph is very important which has been approximated using the widths $\mathrm{W}_{50}$ and $\mathrm{W}_{75}$ at $50 \%$ and $75 \%$ of the peak discharge. The UH width at $\mathrm{W}_{50}$ and $\mathrm{W}_{75}$ can be calculated based on equations (7) and (8) below:

$$
\begin{aligned}
& W_{50}=756 Q_{p}-1.081 \\
& W_{75}=450 Q_{p}-1.081
\end{aligned}
$$

Hence, it is possible to develop the shape, standard time lag, time base, time of peak, and peak discharge of each sub-watershed.

\section{Field data collection}

The elevation data points in some parts of LTB have been limited; therefore additional field surveys using Trimble Geo-XT global positioning system (GPS) have been conducted. The GPS has been used as DGPS and expected to have horizontal and vertical accuracy of $1 \mathrm{~m}$ and $3 \mathrm{~m}$ respectively. The accuracy check between GPS elevation points and top o-sheet elevation points shows good fit. However, the field surveys conducted using GPS has been limited to sub-watersheds having flat terrains. These elevation data points have been integrated in Arc-GIS to develop accurate DEM, as discussed under geo-database section above. The water depths in river channel have been measured using WL-16 U automatic water level sensors procured from Global Water USA. It was decided to have four automatic water level sensors of $25 \mathrm{~m}$ cable length fitted with data logger of capacity 81,800 records. The sensor has $0.1 \mathrm{~mm}$ water level measurement accuracy and can record 10 reading per second. The time duration of $30 \mathrm{sec}$ for monsoon year 2010 and $120 \mathrm{sec}$ for monsoon year 2011 were considered in our field based water-level data measurements. The water-level measurement stations in LTB are Kathore, Visdalia, Ghodsamba and Amli dam. Later, the discharge data from Amli station has been considered for validation of hydrological model. The water-level data from all four discharge stations have been imported in notebook using dedicated software. The output data has standard spread sheet format as * ${ }^{*}$.csv (comma separated by values) and output is acquired in excel format using window-XP compatible water level logger software. These data were used for calculating actual discharge using Stage-discharge curve which were later compared with predicted peak flood discharge.

\section{Results and Discussions}

As discussed earlier, the entire LTB consist of 25 sub-watersheds having average geographical area of $65.7 \mathrm{~km}^{2}$. The sub-watersheds identified are part of river tributaries such as Serul khadi, Damini khadi, Gal khadi, Anjana khadi, Mau-khadi, Rakha khadi, and Vare khadi. The entire database has been developed in Arc-GIS and has been analysed using two spatial data analysis tools viz. project management and measurement tool respectively. The sub-watershed parameters such as geographical area, main river channel length, and length of centroid from watershed outlet were calculated. The attribute data table obtained after sub-watershed analysis along with hydrological parameters has been depicted in Table 1 below. The DEM of LTB at $50 \mathrm{~m}$ cell size has been prepared using topo-maps and GPS survey measurements, as shown in Figure 3. DEM has mean elevation of 83.86 $\mathrm{m}$ with 71.02 as SD value. Maximum and minimum elevation value of DEM is $400 \mathrm{~m}$ and $0 \mathrm{~m}$ respectively. The $\mathrm{z}$-value of each DEM cell has been used to delineate sub-watersheds using BASIN 4.0 software from US-EPA. The slope analysis of 25 sub-watersheds shows a mean value of $26.28 \%$. The sub-watersheds 2, 4, 7 and 14 situated in head watersheds have very high slope in the range of $40-45.0 \%$. However, the sub-watersheds 24 and 25 situated near sea coast have flat slope and their value has been found in the range of $2-2.5 \%$.

The process of estimating the sub-watershed SUH can be described in following steps; (i) Calculate standard lag time using equation (1) based on main channel length, channel length from outlet to centroid point, (ii) Calculate the duration of $\mathrm{UH}$, (iii) Calculate the alternative lag time using equation (3) for 1-hr UH. Thereafter, (iv) time of Peak (Tp) and peak discharge can be calculated using equation (4) and equation (5). In next step (v) the time base $\left(\mathrm{T}_{\text {base }}\right)$ is estimated using equations (6) that can considered important in Unit Hydrograph theory. Finally, (vi) the shape of SUH is very important which is determined by approximating width at $50 \%$ of peak discharge $\left(\mathrm{W}_{50}\right)$ 
Citation: Sudhakar BS, Anupam KS, Akshay OJ (2015) Snyder Unit Hydrograph and GIS for Estimation of Flood for Un-Gauged Catchments in Lower Tapi Basin, India. Hydrol Current Res 6: 195. doi:10.4172/2157-7587.1000195

Page 5 of 10

\begin{tabular}{|c|c|c|c|c|c|c|}
\hline Watershed & L (km) & Lc (km) & Area $(\mathbf{k m})$ & Ave Slope (\%) & $T_{p}(h r)$ & $Q_{p}\left(m^{3} / s\right)$ \\
\hline 1 & 7.33 & 10.52 & 89.27 & 29.11 & 9.85 & 18.22 \\
\hline 2 & 2.35 & 10.44 & 67.88 & 43.70 & 7.78 & 17.49 \\
\hline 3 & 11.68 & 6.61 & 66.16 & 29.71 & 7.80 & 17.50 \\
\hline 4 & 26.72 & 19.56 & 160.78 & 45.57 & 13.23 & 23.93 \\
\hline 5 & 3.75 & 9.56 & 51.35 & 30.39 & 8.86 & 11.76 \\
\hline 6 & 4.73 & 10.25 & 50.66 & 27.73 & 6.86 & 15.39 \\
\hline 7 & 2.68 & 7.14 & 57.67 & 41.58 & 8.27 & 14.25 \\
\hline 8 & 5.59 & 5.94 & 29.82 & 15.66 & 7.84 & 7.81 \\
\hline 9 & 1.51 & 8.39 & 56.29 & 23.88 & 8.65 & 13.24 \\
\hline 10 & 1.98 & 9.75 & 55.59 & 29.13 & 9.65 & 11.60 \\
\hline 11 & 3.49 & 2.34 & 6.77 & 7.80 & 4.33 & 35.07 \\
\hline 12 & 25.62 & 18.00 & 150.52 & 19.09 & 12.77 & 23.26 \\
\hline 13 & 6.22 & 10.38 & 9.27 & 33.65 & 10.38 & 17.87 \\
\hline 14 & 14.65 & 10.97 & 112.64 & 40.13 & 10.99 & 20.42 \\
\hline 15 & 11.15 & 10.03 & 50.99 & 33.18 & 8.65 & 12.01 \\
\hline 16 & 0.11 & 5.17 & 41.96 & 36.61 & 7.26 & 11.97 \\
\hline 17 & 9.60 & 5.75 & 15.54 & 19.75 & 7.10 & 4.55 \\
\hline 18 & 2.76 & 7.88 & 47.26 & 29.75 & 8.44 & 11.41 \\
\hline 19 & 16.57 & 10.55 & 68.04 & 17.77 & 9.52 & 14.40 \\
\hline 20 & 9.62 & 7.65 & 46.45 & 23.34 & 7.68 & 12.45 \\
\hline 21 & 13.64 & 14.21 & 121.36 & 29.62 & 11.96 & 20.12 \\
\hline 22 & 8.55 & 4.86 & 37.98 & 17.74 & 6.59 & 12.08 \\
\hline 23 & 6.13 & 5.63 & 27.11 & 26.78 & 7.90 & 7.04 \\
\hline 24 & 10.45 & 9.07 & 60.27 & 2.70 & 8.23 & 14.97 \\
\hline 25 & 25.32 & 15.80 & 161.54 & 2.77 & 12.27 & 26.05 \\
\hline
\end{tabular}

Table 1: Sub-Watershed Parameters Involved in SUH.

\section{Time of Peak Discharge}
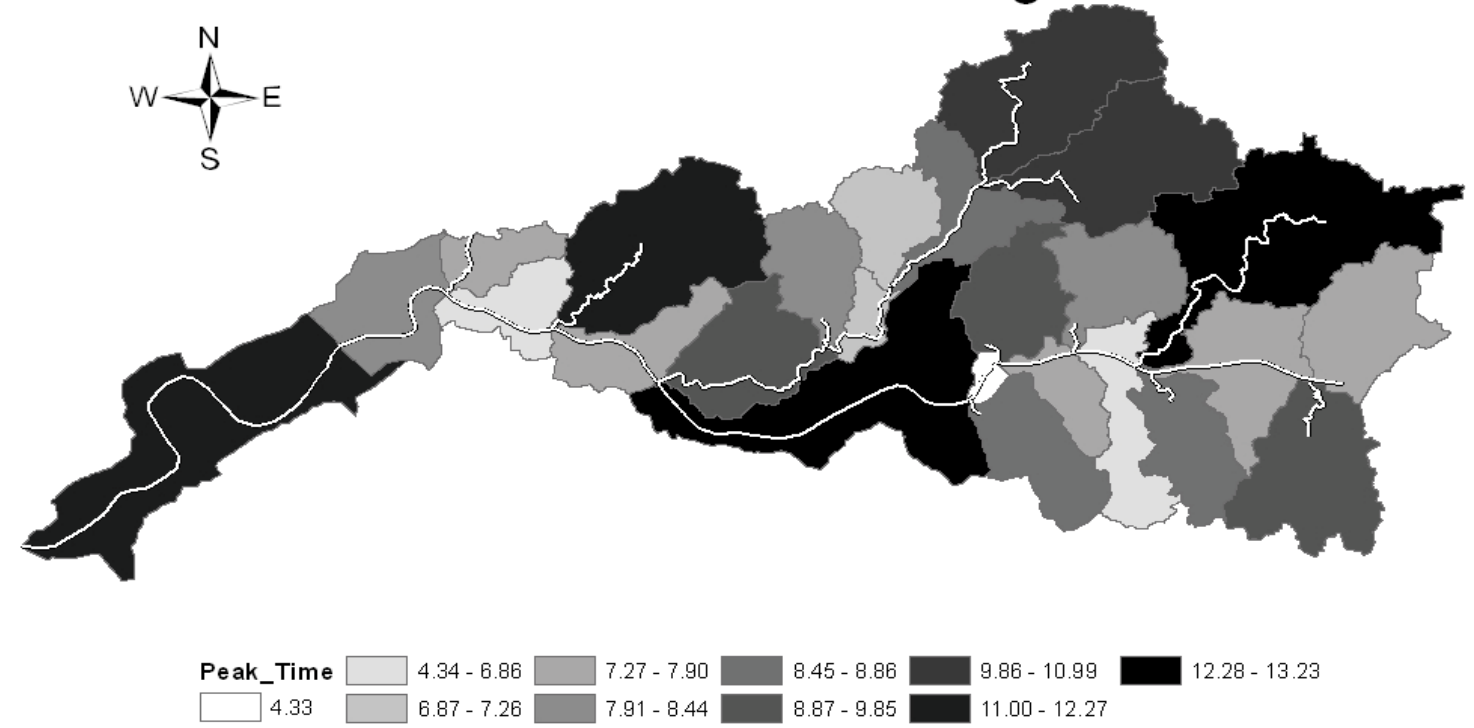

Figure 5: Map showing time of peak discharge for sub-watersheds in LTB.

and $75 \%$ of the peak discharge $\left(\mathrm{W}_{75}\right)$ using the equation (7) and (8). Figure 4 showing time of peak (Tp) shown in Figure 5, however other hydrological parameters are given in Table 1.

The systematic analysis on steps (i) to (vi) as discussed above reveals the following outcome. The value of peak discharge increases when standard lag time decreases, and peak discharge increases when sub-watershed area increases. The sub-watershed level discrete analysis presents that sub-watershed 4,12, 21, 25 have slow response time due to larger watershed area. The sub-watershed 11 has quickest response time due to smaller geographical area and shortest river channel length. Other sub-watersheds like $2,3,6,8,16,17,20 \& 22$ have quick response time due to smaller geographical area and shorter river channel length. In calculating the peak discharge as per equation (5), the sub-watershed 

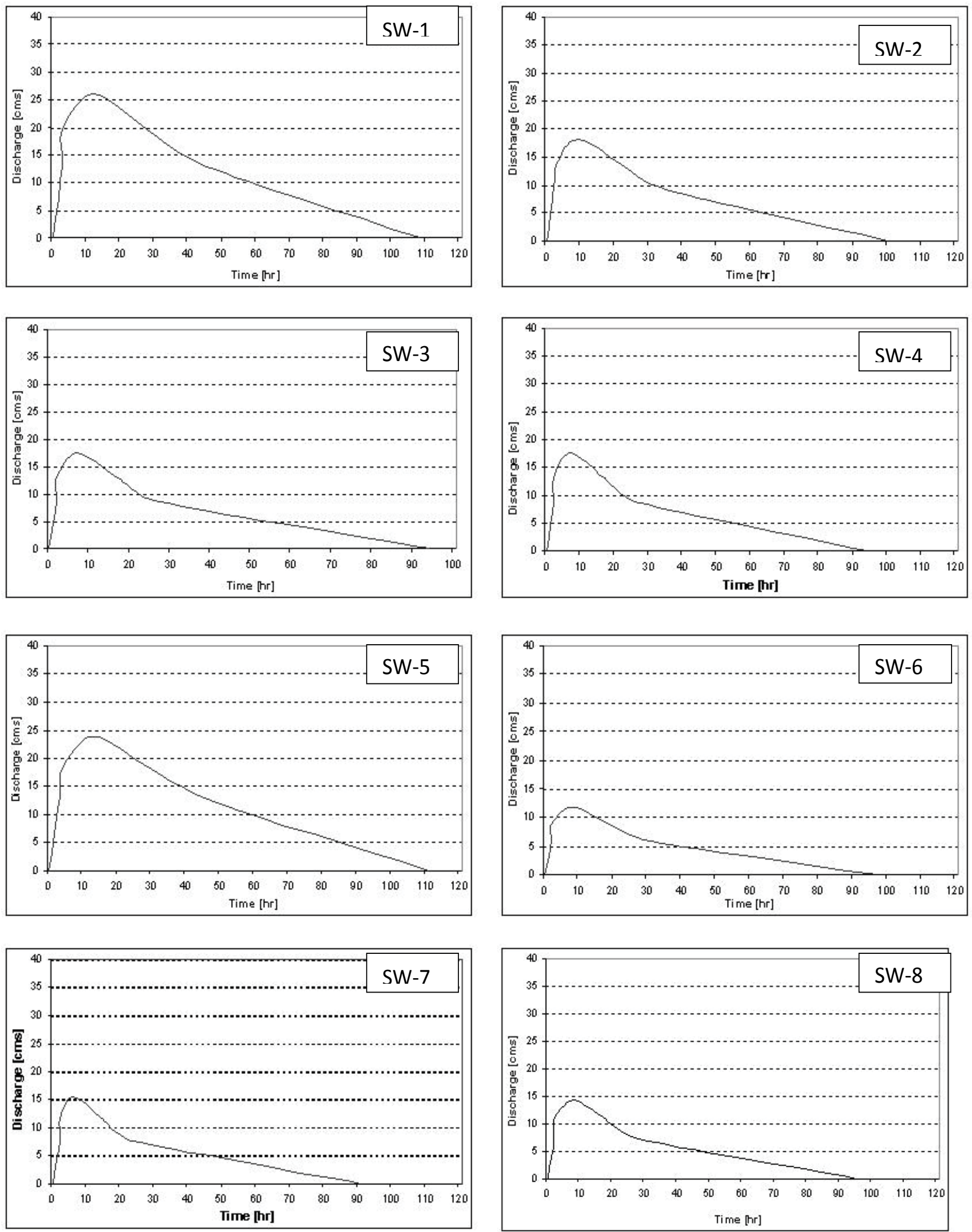

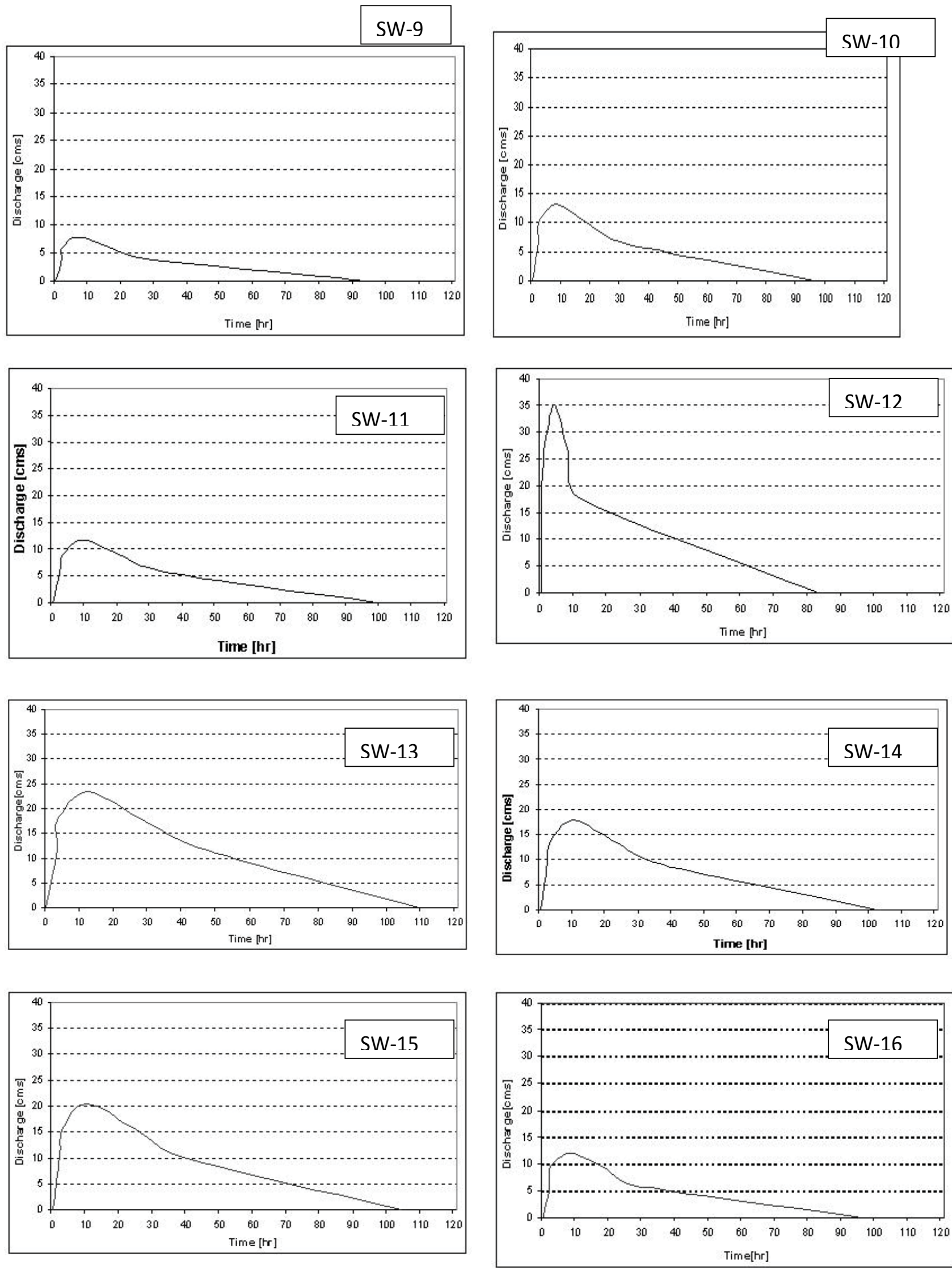

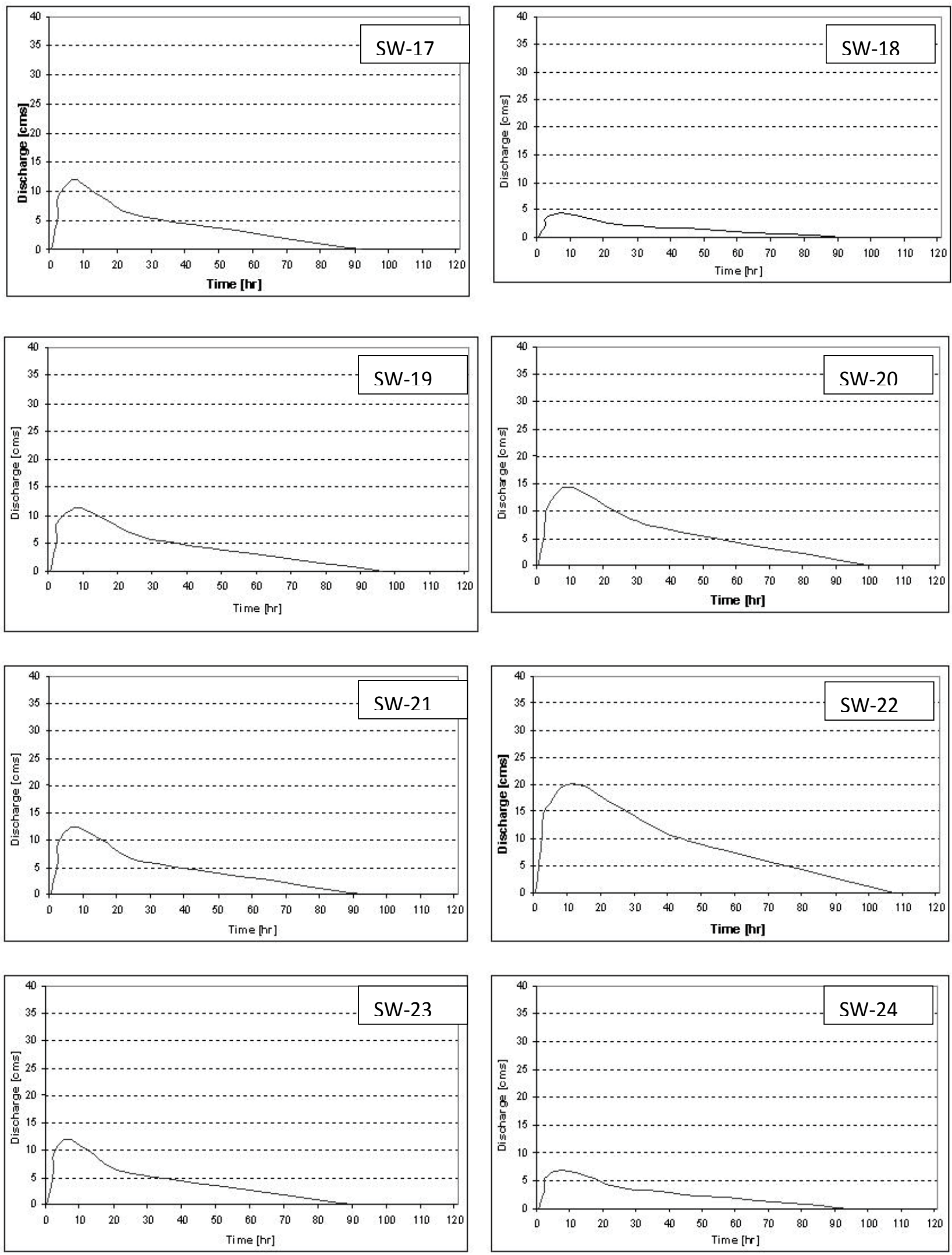

Figure 6: Unit Hydrograph of 25 Sub-Watersheds. 


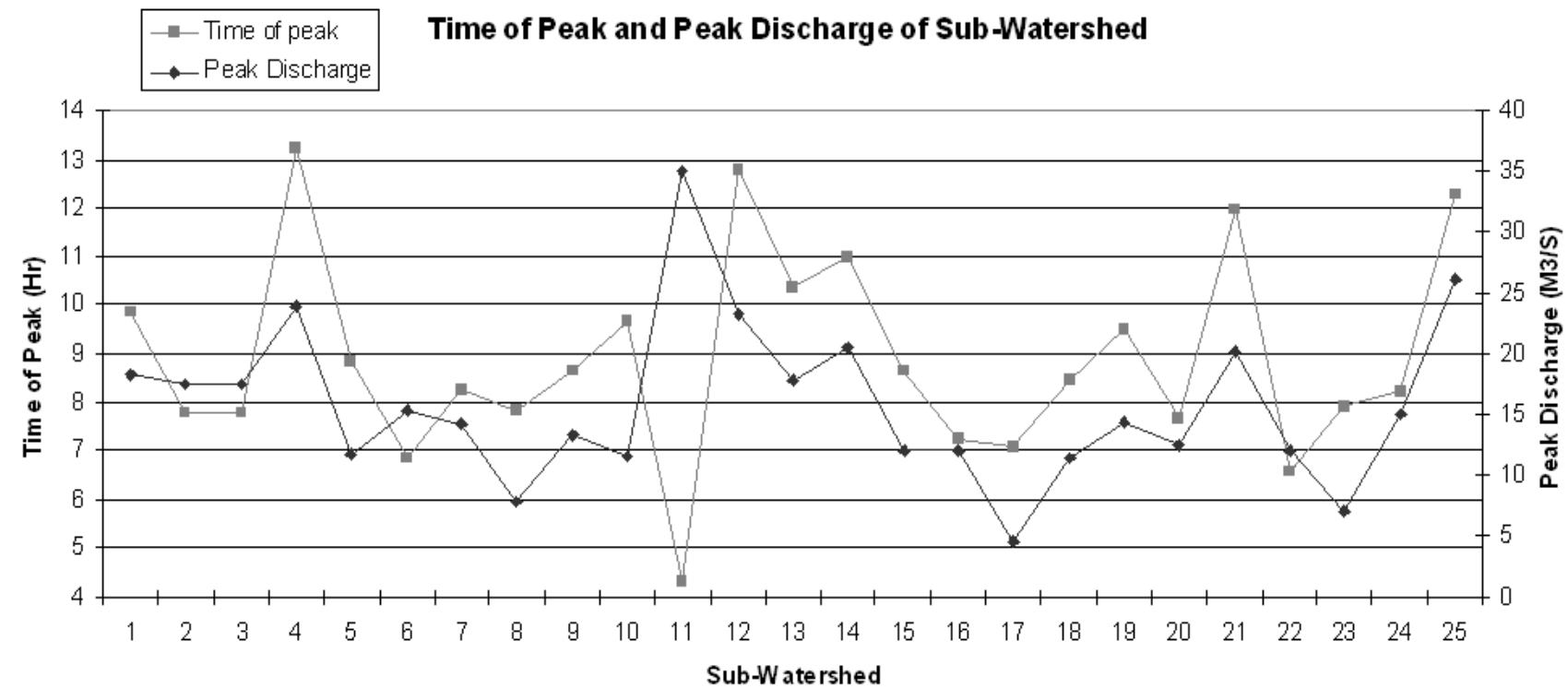

Figure 7: Time of Peak and Peak Discharge of 25 Sub-Watersheds.

\begin{tabular}{|c|c|c|c|c|c|c|}
\hline S.N & Duration & Rainfall (cm) & Discharge (predicted) $\mathrm{M}^{3} / \mathrm{s}$ & Discharge (measured) $\mathrm{m}^{3} / \mathrm{s}$ & Difference & \% Error \\
\hline 1 & July 4-5, 2010 & 4.7 & 80 & 75 & 5 & 6.67 \\
\hline 2 & July10-11, 2010 & 5.5 & 94 & 86 & 8 & 9.32 \\
\hline 3 & August 8-9, 2010 & 11.1 & 191 & 159 & 32 & 16.75 \\
\hline 4 & August 18-19, 2010 & 3.4 & 57 & 54 & 3 & 5.55 \\
\hline 5 & August 24-25, 2010 & 7.9 & 133 & 118 & 15 & 12.71 \\
\hline 6 & August 26-27, 2010 & 6.1 & 104 & 96 & 8 & 8.33 \\
\hline 7 & August 30-31, 2010 & 3.0 & 51 & 47 & 4 & 8.51 \\
\hline 8 & Sep 1-2, 2010 & 2.9 & 40 & 37 & 3 & 8.11 \\
\hline 9 & Sep 6-7, 2010 & 9.6 & 159 & 132 & 27 & 20.45 \\
\hline 10 & Sep 15-16, 2010 & 4 & 68 & 59 & 9 & 8.67 \\
\hline
\end{tabular}

Table 2: Amli Sub-watershed (13) Validation for 2-day Event.

11 gives highest peak discharge due to quick response and smallest geographical area. Sub-watersheds 4, 12, 14, 21 and 25 also gives high discharge value while sub-watersheds 7,8 and 23 gives low discharge value. The sub-watershed 25 has highest area of $161.54 \mathrm{~km}^{2}$, highest discharge of $26.05 \mathrm{~m}^{3} / \mathrm{s}$, and time of peak as 12.27 hours (Figure 7).

The unit response from all the sub-watersheds as $\mathrm{UH}$ has been given in Figure 6. Later, the discharge from UH for few events has been calculated using summation hydrograph (S-hydrograph). Thereafter, the discharge hydrograph for a gauge site Amli has been considered for validation. The observed discharge from WL16 automatic water level sensor and SUH derived discharge have been compared for model validation (Table 2). The peak discharge and runoff volume can be considered an important parameter while deciding the non-structural measures for flood modelling and flood forecasting.

Flooding potential of each sub-watershed was estimated using SUH. The value of Volume and surface runoff were calculated for extracting percentage flood contribution for each sub-watershed which is shown in Table 3. It was found that sub-watershed number 4, 12 and 25 are high flooding potential having percentage contribution 9.24, 8.61 and 9.24 respectively. It was also observed that sub-watershed number 8 , 17 and 23 are low flooding potential having percentage contribution $1.66,0.86$ and 1.50 respectively. Flooding potential depends on peak discharge and area of watershed which is clearly reflected in results found out.

\section{Conclusion}

The SUH method has been chosen for estimation the flood response, contribution of flooding potential, percentage of flood volume for 25 sub-watersheds in LTB. The Geo-spatial database for LTB has been developed and sub-watershed parameters such as river length, length of centroid, spatial area, land use, lateral slope, and terrain and soil factors for estimating discharge. The geo-database developed in ArcGIS environment from topo-sheets (1:50,000), satellite remote sensing images and GPS have been combined and kept in a common database. A DEM of $50 \mathrm{~m}$ cell size has been produced and sub-watershed characterisation was completed. The analysis for all 25 sub-watersheds exhibit that $35.07 \mathrm{~m}^{3} / \mathrm{s}$ and $4.55 \mathrm{~m}^{3} / \mathrm{s}$ and 13.23 hours and 4.33 hours have been highest and lowest peak flows and time to peak respectively. The SUH model has been validated for peak discharge at Amli gauge site where discharge data were collected using water level sensors WL$16 \mathrm{U}$ during monsoon season of the year 2010 and 2011. Measured discharge and SUH estimated discharge shows good fit within a mean variability range of 5-7\%. SUH methods ability to estimate hydrological parameters including peak flow discharge shows wider replication for un-gauged catchments in LTB. Snyder unit hydrograph method could become a good source of information for flood related issues. It gives peak flow estimation with time of peak at a various sub-watersheds is of vital importance in flood forecast as it is useful in computing flood discharge for various rainfall event. 
Citation: Sudhakar BS, Anupam KS, Akshay OJ (2015) Snyder Unit Hydrograph and GIS for Estimation of Flood for Un-Gauged Catchments in Lower Tapi Basin, India. Hydrol Current Res 6: 195. doi:10.4172/2157-7587.1000195

Page 10 of 10

\begin{tabular}{|c|c|c|c|c|c|}
\hline ID & $Q p\left[m^{3} / s\right]$ & Tp [hr] & Volume $\left[\mathrm{m}^{3}\right]$ & Runoff [\%] & Contribution [\%] \\
\hline 1 & 18.22 & 9 & 1147708.45 & 50 & 5.02 \\
\hline 2 & 17.49 & 7 & 849901.78 & 51 & 3.72 \\
\hline 3 & 17.48 & 7 & 786496.15 & 47 & 3.44 \\
\hline 4 & 23.93 & 13 & 2110347.34 & 52 & 9.24 \\
\hline 5 & 11.76 & 8 & 677286.57 & 52 & 2.97 \\
\hline 6 & 15.39 & 6 & 637061.88 & 50 & 2.79 \\
\hline 7 & 14.25 & 8 & 743751.79 & 51 & 3.26 \\
\hline 8 & 7.81 & 7 & 379515.89 & 50 & 1.66 \\
\hline 9 & 13.24 & 8 & 714865.61 & 50 & 3.13 \\
\hline 10 & 11.6 & 9 & 709826.27 & 50 & 3.11 \\
\hline 11 & 35.07 & 4 & 757411.99 & 44 & 3.32 \\
\hline 12 & 23.26 & 12 & 1967536.20 & 52 & 8.61 \\
\hline 13 & 17.87 & 10 & 1189984.87 & 51 & 5.21 \\
\hline 14 & 20.42 & 11 & 1470045.89 & 52 & 6.44 \\
\hline 15 & 12.05 & 8 & 607239.82 & 47 & 2.66 \\
\hline 16 & 11.97 & 7 & 538578.88 & 51 & 2.36 \\
\hline 17 & 4.55 & 7 & 196534.05 & 50 & 0.86 \\
\hline 18 & 11.41 & 8 & 616058.65 & 58 & 2.70 \\
\hline 19 & 14.4 & 9 & 881163.65 & 51 & 3.86 \\
\hline 20 & 12.45 & 7 & 582583.07 & 50 & 2.55 \\
\hline 21 & 20.12 & 12 & 1593293.62 & 52 & 6.98 \\
\hline 22 & 12.08 & 6 & 478304.84 & 50 & 2.09 \\
\hline 23 & 7.04 & 8 & 342098.83 & 50 & 1.50 \\
\hline 24 & 14.97 & 8 & 754388.39 & 49 & 3.30 \\
\hline 25 & 26.05 & 12 & 2109771.42 & 52 & 9.24 \\
\hline
\end{tabular}

Table 3: Volume and surface runoff were calculated for extracting percentage flood contribution for each sub-watershed.

\section{References}

1. Singh AK, Sharma AK (2009) GIS and a remote sensing based approach for urban flood-plain mapping for the Tapi catchments, India, IAHS Publ 331: 389394.

2. Singh AK, Sharma S, Vakharia U, Sharma AK (2011) Estimating hydrological parameters in ungauged basin using field measurements and GIS. Proceedings ISRS2011- Bhopal, 9-11 Oct, 2011.

3. Singh AK, Sharma S, Jain AO (2011) Mapping and predication of surface runoff using SCS-CN method. Proceedings ISG2011 Ajmer.

4. Bhaskar N, Parida B, Nayak A (1997) Flood Estimation for Ungauged Catchments Using the GIUH 123: 4

5. Sharma SB, Singh AK (2014) Assessment of the Flood Potential on a Lower Tapi Basin Tributary using SCS-CN Method integrated with Remote Sensing \& GIS data. J Geogr Nat Disast 4: 2-7.

6. Sherman LK (1932) The relation of hydrographs of runoff to size and character of drainage-basins, Eos, Transactions American Geophysical Union 13: 332339.

7. Sudhakar Sharma B, Anupam Singh K (2014) Lower Tapi Basin Tributary using SCS-CN Method integrated with Remote Sensing \& GIS data. J Geogr Nat Disast 4: 128.

8. Snyder FF (1938) Synthetic unit graphs. Trans Americans Geophysics. Un. 19

9. Hoffmeister G, Weisman RN (1977) Accuracy of synthetic hydrographs derived from representative basin. Hydrological Sciences 22: 297-312.

10. Wayal AS, Parmeswaran PV, Ameta NK (2008) Derivation of unit hydrographs for ungauged catchments, First International Conference on Emerging Trends in Engineering and Technology, pp. 1029-1034.

11. Adebayo WS, Solomon OB, Ayanniyi MA, Sikiru FO (2009) Evaluation of synthetic unit hydrograph method for development of design storm hydrographs for rivers in South-West- Nigeria. Journal of American Science 5: 23-32.

12. Adib A, Salarijazi M, Najafpour K (2010) Evaluation of synthetic outlet runoff assessment models. J Appl Sci environ Manage 14: 13-18. 